\title{
CONFLICT MANAGEMENT IN INDONESIA: Policy Perspective and Analysis
}

\author{
Sugit S. Arjon \\ The Graduate School of International Relations, \\ Ritsumeikan University, Kyoto, Japan \\ Email: gro298vk@ed.ritsumei.ac.jp
}

\begin{abstract}
This article focuses on analysing the roots of violence and examines case studies in Indonesia. This article aims at determining the effectiveness of policies in conflict management by analysing the critical factors involved in violent conflicts and briefly seeking alternative solutions to prevent them from happening in the future. Furthermore, this article aims to answer two central questions. Firstly, this study looks at how effective the Indonesian government's policy on security and conflict is. Secondly, this study considers the roles of NGOs in supporting the effectiveness of the policy on security and conflict. To prevent future conflicts, there are three effective strategies that can be implemented, and they require collaboration between policymakers and society. The first strategy involves designing an effective early warning mechanism, which would be able to inform the government of a potential friction that could escalate to a larger conflict. The second strategy is an effective policy to prevent and manage conflict and provide peace building mechanisms post-conflict. The third strategy is to urge the participation of non-state actors in conflict management. The Indonesian government and House of Representatives (Dewan Perwakilan Rakyat - DPR) have passed a bill on social conflict management written as Law No. 7/20I2 and known as UU PKS. However, UU PKS arguably leaves numerous loopholes. Moreover, the activities of NGOs in conflict management can be divided into two main categories: public engagement and advocacy. Public engagement activities focus on services for the public, while advocacy focuses on maintaining communication and putting pressure on the government. In public engagement activities, NGOs offer services to provide psychological and legal assistance, consulting with victims on their rights as well as providing legal advice and psychosocial support to victims. Moreover, in the advocacy approach, NGOs maintain to put pressure and lobby the government to ensure peace and justice in law enforcement.
\end{abstract}

Keywords: conflict prevention, non-state actors, roots of violence, security policy, peace resolution, peace building

\begin{abstract}
Abstrak
Artikel ini fokus menganalisa akar dari kekerasan dan artikel ini menguji studi kasus dari Indonesia. Artikel ini bertujuan untuk menjawab efektifitas dari kebijakan manajemen konflik di Indonesia dengan menganalisa faktor krusial yang menyebabkan konflik dengan kekerasan dan mencari solusi alternatif untuk menghindari terulang kembali di masa depan. Artikel ini bertujuan untuk menjawab dua pertanyaan utama, pertama, seberapa efektif kebijakan Pemerintah Indonesia di dalam isu keamanan dan konflik. Kedua, apa peranan aktor non-pemerintah untuk mendukung keefektifan kebijakan isu keamanan dan konflik. Untuk mengindari konflik di masa depan, ada tiga strategi efektif yang bisa dimplementasikan dan itu membutuhkan kolaborasi diantara masyarakat dan pembuat kebijakan. Pertama, dengan merancang mekanisme peringatan dini yang efektif yang mampu untuk menginformasikan potensi friksi yang dapat meningkat menjadi konflik yang lebih besar. Kedua, kebijakan publik yang efektif untuk menghindari konflik, untuk mengatur konflik, dan pembangunan perdamaian di dalam pasca konflik. Ketiga, meningkatkan partisipasi aktor non-pemerintah di dalam manajemen konflik. Pemerintah
\end{abstract}


Indonesia dan badan legislatif (DPR-RI) telah memiliki sebuah undang-undang (UU) mengenai konflik sosial yang bernama UU Penanganan Konflik Sosial (UU PKS) atau UU no. 7 tahun 20I2. Akan tetapi UU ini mempunyai beberapa kelemahan. Lebih lanjut, peranan aktor non-negara di dalam manajemen konflik terbagi dua: keterlibatan dengan masyarakat dan advokasi. Keterlibatan dengan masyarakat fokus akan pelayanan kepada publik sementara advokasi fokus pada komunikasi dan tekanan kepada pemerintah. Di dalam pelayanan publik aktor non-pemerintah fokus pada bantuan hukum dan psikologi, konsultasi hak-hak masyarakat atau korban, sementara di bidang advokasi menjaga komunikasi, diskusi, dan lobi terhadap pemerintah untuk memastikan perdamaian dan kepastian hukum terhadap korban atau masyarakat.

Kata kunci: pencegahan konflik, aktor non-pemerintah, akar kekerasan, kebijakan keamanan, resolusi perdamaian, pembangunan perdamaian

\section{INTRODUCTION}

The Oxford English dictionary defines security as the state or condition of being or feeling secure, free from danger or threat and to obtain certainty of safe future. In the hierarchy of needs, a theory proposed by Abraham Maslow, security is listed as the second most important element for humans, after physiological needs such as food, water, and sleep. Security is also a basic principal of human rights, according to the Universal Declaration of Human Rights.

The majority of scholars discuss the concept of security from a political perspective, which aims to protect people from threats and violence. The discussion among well-known scholars has focused on the 'subject' of security or who needs to be secured. On the other hand, after the Cold War, the discussion of security dealt more with the 'object' of security or what needs to be secured, such as the concepts of human security, food security, water security, ecosystem, and so on.

Moreover, globally, the concept of security has experienced serious adjustments in both academic study and among policymakers. After World War II, the concept of security was closely related with the notion of state security and focused more on human security. Threats to security have spread globally, but the impacts remain localised.

In discussions among academics, the concepts of security and peace are treated as two different elements, while in practice, they are often interrelated. Peace is the absence of conflicts or war. For those who have experienced violence, peace is a state of mind, and there is no peace for those who have suffered without justice. Political security in a country is equal to the number of violent conflicts that occur, and the effects of conflict, violence, and insecurity are devastating. Thus, to achieve stability, it is important to avoid and prevent conflict as early as possible.

This article focuses on analysing the roots of violence through case studies in Indonesia. This article also aims at answering the effectiveness of policy in the conflict management by analysing the critical factors that involved in violent conflicts and briefly seek alternative solution to prevent it to happen in the future. Moreover, this article investigates conflict prevention, inspired by the concepts and designs that were proposed by numerous scholars.

Indonesia is an interesting country to study conflict because Indonesia has regularly experienced large-scale violence over the past two decades. Jakarta, Sambas, Poso, Moluccas, and West Papua were areas that were strongly associated with mass killings in late of I990s and early 20oos. Surprisingly, in some areas, such as Poso and West Papua, violence is still prevalent. These situations of conflict often implicate religion, ethnicity, and race as the roots of violence. Moreover, due to the number of fallen victims, Indonesia is considered as a violent country.

Jakarta silently witnessed people being raped, murdered and disappearing in I998. In other cases, since i996, Madurese transmigrates in Sambas clashed with local people in Sampit, which resulted in an uncountable number of 
Madurese people being slaughtered and driven away from their homes. In addition, it can be argued that religious sentiment was used as a basis for violence, causing wars in Poso and Moluccas. Christians attacked and killed Muslims, and the reverse happened in both provinces. These clashes dominated media headlines in late I990s and early 2000 s.

This article analyses the development of domestic political security, which relates to human security. This article aims to answer two central questions. Firstly, this article looks at how effective the Indonesian government policy on security and conflict is. Secondly, this article considers the roles of NGOs in supporting the effectiveness of the policy on security and conflict. Furthermore, the concept of security in international relations studies is defined as the ability of a state to protect itself from internal and external threats or danger, such as civil wars, interventions, communal conflicts, invasions, and attacks. The facts show that Indonesia is prone to conflicts. However, academic articles that discuss Indonesian governmental policy on conflict are limited. Hence, this article seeks to fill a gap in the discussion of conflict in Indonesia.

Additionally, the spread of violence across Indonesia points to the importance of conflict prevention studies. Interest in halting violence in Indonesia is growing. The topic is attracting the media, NGOs, and the academic world, and thus it is appealing to investigate this topic in this study. Security issues in a state can be identified by the total number of conflicts. It is important for a state to prevent conflict and maintain peace to achieve stability and to examine every possible way to prevent conflicts from erupting through an effective policy on conflict, which includes boosting assistance and cooperation from civil society, including NGOs. The first chapter of this article examines the roots of violent conflicts. The second chapter discusses conflict prevention and includes a lengthy analysis of the Indonesian government's policy on conflict followed by a discussion of the roles NGOs can play to support this strategy. The conclusion is followed by a list of the works cited in this article.

\section{VIOLENT CONFLICTS}

Violence is a practice that involves force, physi$\mathrm{cal}$, and damage to someone or something. To be able to prevent violent conflicts from erupting, it is important to grasp the roots of violence. Since the independence in I945, Indonesia regularly experience violence, namely, Madiun upraising in I948, universal struggle (Perjuangan Semesta - Permesta) in 1957, the Revolutionary Government of the Republic of Indonesia (Pemerintah Revolusioner Republik Indonesia - PRRI) in I958, massacre in I965-I966, Malari (Malapetaka Lima Belas January) incident in I974, mysterious shootings (Penembakan Misterius - Petrus) between I982 and I985, Tanjung Priok massacre in 1984, Talangsari massacre in 1989 , riots in $27^{\text {th }}$ of July I996 (Kerusuhan Dua Puluh Tujuh Juli Kudatuli), and Semanggi incidents and riots in May 1998. Hence, based on what happened in the past and what evidence shows, Indonesia is arguably a violent country. The facts show that since its independence, numerous Indonesians have lost their lives due to conflicts. Despite economic and national political reforms, domestic security issues remain important because they implicate religious violence, communal conflicts, and ethnic violence, which continue to pose a threat to people.

There are few arguments explaining why violent conflict occurs. For example, reasons can be socio-economic. In addition, violent conflicts are driven by the rise of intolerance, mainly with regard to ethnicity, race, gender, and religion. Some scholars argue that acts of intolerance are commonly triggered by poverty as well as political, social, and economic inequalities between groups, which lead to conflict. As stated earlier in this article, Indonesia has regularly experienced large-scale violence in the past two decades, which frequently involve religion, ethnicity, and race as the roots of violence. This shows that Indonesia is prone to conflicts. Even though Indonesia is a violent country and is prone to conflicts, the Indonesian government seems to lack a domestic security strategy to address threats, such as religious violence and ethnic conflicts.

Moreover, Indonesia's society consists of numerous ethnic groups, races, and religions. 
Indonesia has the world's largest Muslim population, and the government recognises five other religions, including Protestant, Catholic, Hinduism, Buddhism, and Confucianism. Since there is a great amount of diversity in Indonesia, people are prone to conflict. Due to this diversity, violent conflicts could remain unless the main reasons for and roots of the violence are resolved.

Violent conflicts do not only occur because of extensive disagreement. Nordholt (2002) defined violent conflicts as the use of force or the threat of using force with the intention of bringing harm to others. Violent conflicts occur due to several reasons. Normally, larger conflicts occur because of individual conflicts. They normally erupt when there is a threat against people's needs and interests. Social class conflicts erupt as a result of socioeconomic gaps. Identity conflicts involve aspects of identities such as race, ethnicity, and religion.

One of the most common conflicts happened in Indonesia due to religious identities. Religious identities can transform political conflicts in ways that ideologies and organisations cannot. For instance, the conflict in Ambon in I999 illustrates how political policies disrupt the balance of forces between two communities. Ambon quickly became the disastrous place of an inter-religious battle. Since religious identity played a role in the competition for power in the Moluccas, the government policy complicated things and managed to increase the fear and security of one community and permitted violent expression and use religion as a basis for a group identity (Bertrand).

Religion has always stirred heated tensions and high emotions in Indonesia, especially at the end of the New Order (ORBA) regime in the late I990s. "The outbreak of violence and anger was a direct consequence of high tensions regarding religious and racial sentiments. It is difficult to examine and understand religious conflict, violent religious nationalism, religious civil wars, or religious terrorism because they have logic or causal textures of their own, which set them apart from other forms of conflict and violence" (Brubaker 2).
Moreover, religious conflict and violence tend to erupt and spread more quickly than other forms of conflict and violence in Indonesia. Religion is often considered a central part of identity. However, religious identities cannot be separated from larger identity consciousness structure such as ethnicity, language, race, caste, tribe, kinship, and region.

Brubaker (2015) explains that there is no intrinsic connection between religion and political violence. However, religion does provide a mass of moral, ideological, and organisational resources at the personal level that can, in certain contexts, inform, legitimate, or sustain admirable forms of moral and political engagement. Religious factors are introduced into conflict through fear to play on local insecurities, among other factors. Those who take part in violent conflicts are not interested in political issues, democratisations, or contestations of power, which influence the conflict. For them, it is all about religion. Political or economic issues are just camouflages used for the destruction of a religious community (Duncan). The violent conflict that occurred in North Maluku is a perfect example on how political issues are just the camouflages. The conflict in Tobelo erupted because it was a fight between two irrational blind faiths. The triggers are diverse such as politics, economic, change of a regime, but the opposing parties tend to use religions as their main arguments.

Furthermore, when the roots of conflict or violence are ethnic, racial, and religious, it is important to involve mass organisations, such as religious, racial, and ethnic institutions, in conflict management. It is also important to mobilise cultures and traditions toward peace. Brauchler (2009) argues that culture can be an effective means to build inter-religious bridges and foster reconciliation.

Braithwaite (2013) argues that religious, racial, and ethnic institutions played a positive role during the conflict in Ambon in 2002. Muslim fighters decided to return to their homes and live peaceful lives after respected leading clerics persuaded them using religious terms and diplomacy. The fighters were willing to shut down their organisations and things that might 
lead them back into violent conflict' willingness to shutting down their organisations and things which may lead them back into violent conflict.

\section{CONFLICT PREVENTION}

Conflict prevention is a short-term and long-term strategy and is both structural and operational. Various actors should be proactively engaged in order to identify the indications of conflict and to create a secure environment. In the discussion of violent conflicts in Indonesia, it is important to look at the facts of the past. There were many major violent conflicts, namely the 1965 mass killings, I998 riots, conflict in Moluccas, massacre in Sampang, tragedy in Poso, and violence in Papua. These were major violent conflicts in Indonesia with high numbers of victims, and these were not ideal portrayals of a safe and secure environment.

To prevent future conflicts, there are three effective strategies that can be implemented and require collaboration between policymakers and society. The first strategy involves designing an effective early warning mechanism which would be able to inform the government of a potential friction that can escalate to a larger conflict. This mechanism requires robust and trusted communication inter-state, inter-society, and between the state and the society. The role of NGOs is larger in early warning mechanism because of their activities at the grass-roots level. They are working on the front lines to provide humanitarian assistance and protection. Due to their location and services, NGOs have the potential to spread early warnings because they are the first to become aware of tensions and conflicts in their early stages (Jentleson 306).

The second strategy is an effective policy to prevent and manage conflict and provide peacebuilding mechanisms post-conflict. This strategy must be supported by a system of law enforcement that is impartial, fair, and supportive of reconciliation attempts. The third strategy involves urging the participation of non-state actors in conflict management. Nonstate actors are useful in all three elements of conflict management: before a conflict, during a conflict, and post-conflict, ass an example,
NGOs are working on the field. Hence, when a conflict erupts, they become field officers that may distribute food, medical supplies, and other aid (Hauss). This discussion is elaborated below in the chapter on the role of NGOs.

This article defines conflict prevention as any attempt to keep tensions and disputes from escalating into significant violence and strengthen capabilities of solving disputes peacefully, which cuts down problems (Ackermann). The principle of conflict prevention is to prevent destructive, violent, and deathly conflict at the earliest point and lowest level. Most conflicts that lead to a number of fatalities are the result of the snowball effect. The conflicts develop over years, rather than days or months. Thus, conflict prevention at the earliest point in time is valuable in terms of human casualties and financial costs. This is why preventing conflict at the earliest time should be considered a main priority in the security sector.

Conflict prevention has consistently been framed in policy recommendations in order to be implemented domestically at the state level, but it is rather poor in practice. Considering that the concepts of security and conflict prevention have advanced and undergone serious adjustments, it is important to examine how to effectively use domestic policy to manage conflict, especially in conflict-prone countries such as Indonesia.

Managing conflict consists of three important stages: before the conflict, known as conflict prevention; during the conflict; known as conflict management; and postconflict, known as peacebuilding. Previous studies show that conflict prevention is limited only to the early stages of conflict and nonescalatory stages of conflict (Ackermann). To gain an understanding of conflict prevention, policymakers need to focus on activities that are essential in combating the escalation of conflict (Scherrer). Moreover, to prevent the outbreak of conflict, there are two major initiatives that governments could launch: executing an effective bill to be implemented at the local level and inviting ideas from parties outside of government, such as NGOs, religious institutions, and ethnic communities. 


\section{Policy initiative on conflict management}

As many domestic violent conflicts have erupted over the past decades, Indonesia needs a serious approach, a theoretical framework, and attention to policy by its government. Since the violent conflicts in Indonesia are treated as matters of urgency, the Indonesian government and house of representatives have passed a bill on social conflict management, called Law No. 7/2012 and known as UU PKS. Law No. 7/20I2 is arguably considered as a progress of Indonesia after having numerous violent conflict post I998. According to its name, UU PKS solemnly focuses on managing conflict, instead of preventing conflict. However, it acknowledges conflict prevention in some of its articles. Moreover, based on Law No. 7/20I2, the Indonesian government established government regulation No. 2 in 2015 on the implementation of a social conflict management bill. However, UU PKS arguably leaves many loopholes open.

First, UU PKS emphasises the mechanisms for and limitations of human rights enforcement. The state is meant to ensure, provide, and offer full protection of human rights. However, this principle is not seen in UU PKS. All of the 62 articles in UU PKS demonstrate that the Indonesian government chooses to react to conflict, rather than prevent conflict.

Second, there is a strong correlation between low-intensity conflict and law enforcement. Moreover, UU PKS does not firmly specify that law enforcement is needed to prevent or handle conflicts. Successful peacebuilding attempts in some post-conflict areas rely on law enforcement. There can be no peace without justice. Involving law enforcement is one of the crucial steps toward peace.

Third, Chapters $12,33,34$, and 35 in UU PKS mention the possibility of involving the Indonesian National Armed Forces (TNI) in conflict management. The involvement of TNI in a civil issue, especially in conflict management, is not a wise move, both politically and socially. The involvement of $\mathrm{TNI}$ in a civil issue is an act that reminds the Indonesian people of when the military had a dual function during the era of dictatorship under President Suharto's regime.
The military had two roles, first, they had the obligation of preserving and enforcing the security and sovereignty of the state. Second, they held power and governed the state, controlling government policy. Involving the TNI would be a setback in conflict management, and the situation would probably worsen.

Fourth, many violent conflicts happen because of the differences between the expectations and reality - between desire for what could be and the reality of what is (Galtung). To understand how conflict prevention works, it is important to grasp why or how conflicts erupt in the first place. The law UU PKS points out the roots of violent conflict in Indonesia. Most conflicts are associated with politics, the economy, socio-cultural issues, religion, ethnicity, race, territorial disputes, natural resources, and inequality in the distribution of natural resources. However, UU PKS points out the policymakers in Indonesia would not necessarily be able to find accurate and effective solutions if the government focuses on reacting to conflict instead of trying to overcome the roots of violence.

Moreover, UU PKS leaves out the crucial role of individuals, civil society, ethic communities, NGOs, religious institutions, etc. The key lesson is that UU PKS is indeed still very much state-centred. In a globalised era, it is arguably correct that the role of state has been diminished. The changing role of the state is due to the growing role of external actors in world politics, such as civil society, NGOs, religion institutions, etc. In addition, UU PKS is still using a top-down approach with barely any initiatives to share responsibilities with the actors stated earlier.

Fifth, the UU PKS arguably leaves loopholes because some of its articles contradict with other laws, such as a bill on Indonesia's defence force, Law No. 34 of 2004 and the government regulation in lieu of law No. 23 of I959 on declaring a state of emergency. More importantly, UU PKS does not do much in terms of conflict prevention. Conflict prevention is needed to protect civilians because they are considered soft targets that are easy to assault. The majority of civilians in conflict zones are 
murdered, tortured, starved, harmed, expelled, and displaced, rather than protected (Scherrer).

The mechanism for conflict prevention within UU PKS can be used as a tool to avoid gross violations of international law. However, the PKS needs to be heavily revised to avoid confusion and prevent overlap with other bills. In short, conflict prevention aims to prevent the escalation of conflicts into armed conflicts. It also aims to prevent past conflicts from reoccurring and current conflicts from spreading. Hence, UU PKS needs to address more of these matters.

In addition, it is important to approach many actors and encourage them to become involved in conflict management. All parties can play different roles in society. For example, the state provides competent and effective conflict prevention policies, whereas non-state actors, such as NGOs, religious institutions, and members of civil society, provide valuable advice to the state, since their daily activities involve dealing with people at the grass-roots level. Moreover, as stated earlier, UU PKS is still state-centred, with little involvement of non-state actors in conflict management, especially conflict prevention. It is important to acknowledge and examine the roles of non-state actors in conflict management.

\section{Role of non-state actors in conflict preven- tion}

Timing is essential in conflict prevention. Once violence erupts, harm begins to increase, and prevention is limited. The history of conflict zones shows that once violence erupts, mediation and other forms of dispute resolution become more difficult. Early responses aim to reduce the damage of conflict and rescue more lives. The role of non-state actors is vital in all three stages of conflict management: before the conflict, during the conflict, and post-conflict.

Statistically speaking, prevention is far more effective and less costly in terms of blood and money, as opposed to responding after conflicts. However, the state has been the main actor in conflict prevention, and the role of civil society, including NGOs, in conflict prevention is yet to be explored. There are three factors that can effectively support the conflict prevention agenda. First, detailed knowledge of which areas are at risks is required. Second, policymakers must fully understand the comprehensiveness and flexibility of policy instruments that can be applied in long-term and short-term. Additionally, conflict prevention must involve strong political will (Evans 8I).

Table I. Conflict Management by Non-Government Organisations

\begin{tabular}{|c|c|c|}
\hline Categories & Public Engagement & Advocacy \\
\hline $\begin{array}{l}\text { Local } \\
\text { NGOs }\end{array}$ & $\begin{array}{l}\text { Seminars, workshops, psy- } \\
\text { chological and legal assis- } \\
\text { tance, consulting citizens, } \\
\text { orientation, legal advice, } \\
\text { psychosocial support, and } \\
\text { providing institutional } \\
\text { strength to victims }\end{array}$ & $\begin{array}{l}\text { Peace council, hear- } \\
\text { ing, lobbying at local } \\
\text { level, promote peace, } \\
\text { academic research, } \\
\text { and discussion }\end{array}$ \\
\hline $\begin{array}{l}\text { Interna- } \\
\text { tional } \\
\text { NGOs }\end{array}$ & $\begin{array}{l}\text { Urgent letter, condem- } \\
\text { nation of acts, global } \\
\text { pressure, conflict media- } \\
\text { tion }\end{array}$ & $\begin{array}{l}\text { Lobby at interna- } \\
\text { tional level between } \\
\text { the governments } \\
\text { through their em- } \\
\text { bassies at conflict } \\
\text { zones }\end{array}$ \\
\hline $\begin{array}{l}\text { National } \\
\text { NGOs }\end{array}$ & $\begin{array}{l}\text { Negotiation, support } \\
\text { for peace activists at } \\
\text { national level, public } \\
\text { campaigns, conflict } \\
\text { mediation, change in } \\
\text { mentality, political mo- } \\
\text { bilisation, public actions, } \\
\text { social mobilisation, } \\
\text { social pressure, gather- } \\
\text { ing emerging victims, } \\
\text { discussing concepts of } \\
\text { peace and justice, victim } \\
\text { reparation, street pres- } \\
\text { sure, and legal pressure }\end{array}$ & $\begin{array}{l}\text { Comprehensive } \\
\text { reports, lobbying } \\
\text { at national level, } \\
\text { promoting peace in } \\
\text { international level } \\
\text { via policies, closed } \\
\text { door diplomacy, } \\
\text { academic research, } \\
\text { discussion, lobby- } \\
\text { ing government } \\
\text { authorities, discus- } \\
\text { sions, correspond- } \\
\text { ing public policy, } \\
\text { and dialogues }\end{array}$ \\
\hline
\end{tabular}

Source: Arjon (2015)

The first element of conflict management involves formulating how to lessen tensions thus the situation does not escalate into a conflict. Apart from the effective implementation of policy from the government, there are things that can be done by NGOs to prevent conflicts from erupting in both the short-term and long-term. Law enforcement remains the key to preventing conflicts from erupting. By implementing the appropriate policies to help prevent conflict, a policymaker is also committed to establishing an environment that 
maintains peace, which supports the human rights agenda in the struggle against violence.

The activities of NGOs in conflict management can be divided into two main categories: public engagement and advocacy. Previously, NGOs were not involved in politics and advocacy and simply worked on public engagement, focusing on providing services to the public. However, since the end of the Cold War, the role of NGOs has evolved, and it is now not limited to providing services to the public. Table i shows activities and actions that local, national, and international NGOs take in public engagement and advocacy. Local NGOs are defined as NGOs that work in provincial areas; National NGOs are defined as NGOs that work at the national level. International NGOs are defined as NGOs that have global branches and are not only based in one country.

There are two activities that NGOs can do to support the government in its conflict management bill: public engagement and advocacy. Public engagement activities focus on services to the public, while advocacy focuses on maintaining communication and putting pressure on the government. For public engagement, NGOs focus on services to the public. Non-governmental organisations can serve as a bridge between the public and the government. For example, in I998, during riots in Indonesia, human rights NGOs received reports of rapes from victims, families, and friends (Min).

Non-governmental organisations provide psychological and legal assistance, consulting victims regarding their rights and offering legal advice and psychosocial support to the victims of the 1998 riots. Moreover, as part of the advocacy approach, NGOs maintain to put pressure and lobby the government at the same time to ensure peace and justice in law enforcement. Non-governmental organisations commit to establishing domestic and international pressure on the government by maintaining communication with the public and international community. Handling the I998 riots in Indonesia was an ideal example of how NGOs provide much-needed support for victims and their families. At the same time, they were redefining public knowledge of events.

Non-governmental play more advanced roles, as demonstrated in the table above. In this strategy, NGOs act more like watchdogs over the government on human rights issues. In cases in Indonesia, it has been proven that NGOs reports on human rights were capable of putting pressure on the government. Reports from NGOs were capable of bringing rape cases and human rights violations to the local and international public's attention. In I993, an international NGO exposed abuses committed by two opposing parties in Aceh: The Free Aceh Movement (GAM) and TNI. The report was produces by the NGO based on interviews with Acehnese civilians (Drexler).

Moreover, a state needs to maintain its credibility. Thus, inviting NGOs to participate as neutral actors is needed. In addition, it is important for members of civil society and NGOs to serve as bridges between opposing parties. Furthermore, the political participation of members of civil society in peace talks shows the importance of these processes in achieving and maintaining peace. It is important to acknowledge and encourage collaboration and participation of governments and civil society in advance, rather than maintain states perspectives.

Moreover, society plays an important role in promoting peaceful conflict resolution in Indonesia. For example, an NGO worked with GAM and the Indonesian government to achieve peace in Aceh. The negotiation began in 2000, and in 2004, both parties reached an agreement to end conflict and war in Aceh. Non-governmental organisations In Indonesia, NGOs have been involved in many activities intended to strengthen the role of civil society in solving social problems and facilitating peaceful social transformations (Panggabean 225).

\section{CONCLUSION}

Indonesia has experienced regular conflict violence since its independence. The spread of violence over the past two decades reflects the importance of laws on security and conflict. 
The Indonesian government understands the urgency of establishing an effective policy. Having experience a dark period post-I998, Indonesian government is aware that it is necessary to establish a new law which manage the prevention of violent conflicts. Since 20I2, Indonesia has instated a policy called UU PKS, which guides and manages the Indonesian position on security and conflict. However, the law is not effective due to several loopholes in its articles.

One of the most common conflicts happened in Indonesia due to religious identities. Religious identities spread faster because it can transform political conflicts in ways that ideologies and other ideologies cannot because religion is often considered a central part of identity. However, in the context of Indonesia, religious identities cannot be separated from larger identity consciousness structure such as ethnicity, language, race, caste, tribe, kinship, and region. Religious factors are introduced into conflict through fear to play on local insecurities, among other factors

This law is not effective because its articles emphasise limitations to human rights enforcement. The chapters in UU PKS show that the Indonesian government reacts to conflict, instead of trying to prevent the conflict. Second, UU PKS is not effective because it does not firmly specify that law enforcement is essential to prevent and handle conflict. Third, involving the military in civil issues is not a wise political or social move. The involvement of the military is considered an obstacle in dealing with the issue of conflict management. Fourth, the articles of UU PKS do not aim to overcome the roots of violence in Indonesia. More importantly, UU PKS is state-centred, and the roles of actors outside of the government is limited. Fifth, UU PKS articles contradict with other laws, such as the bill on Indonesia's defence force No. 34 of 2004 and the government regulation in lieu of law No. 23 of 1959.

Moreover, to support the effectiveness of UU PKS, there are roles that NGOs can play. First, they can support the Indonesian government through early warning mechanisms because NGO activities take place at the grass-roots level. Hence, NGOs are the first to become aware of tensions and conflicts in their early stages. Second, NGOs are important for both victims and the government post-conflict during peace building. For the victims, NGOs are able to provide psychological and legal assistance, consult victims on their rights and offer legal advice and psychosocial support. At the same time, they need to maintain their communication with the government to ensure peace and justice in the system of law enforcement. Non-governmental organisations are able to use their local and international networks to put social pressure on the government. At the same time, NGOs are on the front line of redefining public knowledge of events.

\section{REFERENCES}

Ackermann, A. (2003). The Idea and Practice of Conflict Prevention. Journal of Peace Research, 40(3), 339-347.

Arjon, S. S. (2015). Political Influence of Local and International NGOs in Domestic Policymaking Processess: Kidnapping Prevention in Colombia. Master's Thesis at University of Amsterdam, I-70.

Bertrand, J. (2004). Nationalism and Ethnic Conflict in Indonesia. Cambridge: Cambridge University Press.

Brubaker, R. (20I5). Religious Dimensions of Political Conflict and Violence. Sociological Theory, 33(I), I-I9.

Craig, G. A., \& George, A. L. (1995). Force and Statecraft: Diplomatic Problems of Our Time. New York: Oxford University Press.

Drexler, E. (2006). Provoking violence, authenticating separatism: Aceh's humanitarian pause. In C. A. Coppel, Violent conflicts in Indonesia: analysis, representation, resolution (pp. I63-I73). New York: Routledge.

Duncan, C. R. (2013). Violence and Vengeance: Religious Conflict and Its Aftermath in Eastern Indonesia. New York: Cornell University Press.

Evans, G. (2008). The Responsibility to Protect: Ending Mass Atrocity Crimes Once and For All. Washington D.C: The Brookings Institution Press.

Galtung, J. (1969). Violence, Peace, and Peace Research. Journal of Peace Research, 6(3), I67-I9I. 
Hauss, C. (200I). International Conflict Resolution: International relations for the 2Ist century. New York: Continuum.

Jentleson, B. W. (I998). Preventive diplomacy and ethnic conflict: Possible, difficult, necessary. In D. A. Lake, \& D. Rothchild, The international spread of ethnic conflict: fear, diffusion, and escalation (pp. 293-3I6). Princeton: Princeton University Press.

Min, S. S. (2006). 'Eventing' the May I998 affair: problematic representations of violence in contemporary Indonesia. In C. A. Coppel, Violent conflicts in Indonesia: analysis, representation, resolution (pp. 39-57). New York: Routledge.

Nordholt, H. S. (2002). A genealogy of violence. In F. Colombijn, \& J. T. Lindblad, Roots of violence in Indonesia: Contemporary violence in historical perspective (pp. 33-62). Leiden: KITLV Press.

Panggabean, S. R. (2006). Educating to handle conflict and avoid violence. In C. A. Coppel, Violent conflicts in Indonesia: analysis, representation, resolution (pp. 217-228). New York: Routledge.
Scherrer, C. P. (2002). Structural Prevention of Ethnic Genocide. New York: Palgrave MacMillan.

Shapiro, D., \& Kinon, A. (2010). The Prevention Principle: A Pragmatic Framework to Prevent Destructive Conflict. Journal of International Dispute Settlement, I(2), 30I-3I2.

Stewart, F. (2002). Horizontal Inequalities as a Source of Conflict. In F. O. Hampson, \& D. M. Malone, From Reaction to Conflict Prevention: Opportunities for the UN System (pp. I05-I38). London: Lynne Rienner Publishers.

United Nations Press Releases. (2004, 4 7). Meetings Coverage and Press Releases. Retrieved I2 I9, 20i6, from United Nations: https://www. un.org/press/en/2004/sgsm9245.doc.htm

Varshney, A., Tadjoeddin, M. Z., \& Panggabean, R. (20I0). Patterns of Collective Violence in Indonesia. In A. Varshney, Collective Violence in Indonesia (pp. I9-50). London: Lynne Rienner Publishers. 